\title{
ANTI- Helicobacter pylori ACTIVITY OF PLANT EXTRACTS TRADITIONALLY USED FOR THE TREATMENT OF GASTROINTESTINAL DISORDERS
}

\author{
Laura Lúcia Cogo ${ }^{1,2 *}$; Cristina Leise Bastos Monteiro²; Marilis Dallarmi Miguel ${ }^{3}$; Obdulio Gomes Miguel ${ }^{3}$; Miriam \\ Machado Cunico $^{3}$; Marcelo Lima Ribeiro ${ }^{4}$; Eloá Ramalho de Camargo ${ }^{4}$; Gislene Maria Botão Kussen² Keite da Silva \\ Nogueira $^{1,3}$; Libera Maria Dalla Costa ${ }^{1,2,3}$
}

${ }^{1}$ Hospital de Clínicas da Universidade Federal do Paraná, Curitiba, PR, Brasil; ${ }^{2}$ Programa de Pós Graduação em Processos Biotecnológicos da Universidade Federal do Paraná, Curitiba, PR, Brasil; ${ }^{3}$ Programa de Pós Graduação em Ciências Farmacêuticas da Universidade Federal do Paraná, Curitiba, PR, Brasil; ${ }^{4}$ Laboratório de Microbiologia e Biologia Molecular da Unidade Integrada de Farmacologia e Gastroenterologia da Universidade São Francisco, Bragança Paulista, SP, Brasil.

Submitted: April 07, 2009; Returned to authors for corrections: May 19, 2009; Approved: October 06, 2009.

\begin{abstract}
The antibacterial activity of plant extracts obtained from Bixa orellana L., Chamomilla recutita L., Ilex paraguariensis A. St.-Hil., Malva sylvestris L., Plantago major L. and Rheum rhaponticum L. has been evaluated against two reference strains and eleven clinical isolates of Helicobacter pylori. All the plant species chosen are used in popular Brazilian cuisine and folk medicine in the treatment of gastrointestinal disorders. Initial screening was made by the disk diffusion test and then minimum inhibitory concentration was determined by the agar dilution method. The results presented in this work demonstrated that among the plant preparations analyzed, B. orellana L., C. recutita L., I. paraguariensis A. St.-Hil. and $M$. sylvestris L. were capable of inhibiting the in vitro growth of $H$. pylori.
\end{abstract}

Key words: Helicobacter pylori, antibacterial activity, plant extracts.

\section{INTRODUCTION}

Helicobacter pylori is a Gram-negative spiral-shaped bacterium that was first isolated by Barry Marshall and $\mathrm{J}$. Robin Warren. Since its discovery in 1983, the microrganism has been associated with the etiopathogenesis of several diseases of the digestive system, such as gastritis, peptic ulcer disease and gastric cancer (11). Conventional treatment for eradication therapy of these infections is mainly based on the use of multiple drugs, such as clarithromycin, amoxicillin, furazolidone, tetracycline and metronidazole with bismuth or a proton pump inhibitor (15).

Although the conventional treatment for eradication therapy of $H$. pylori allows obtaining high cure rates, eradication failure rate remains of 5-20\%. This fact may be partially explained by non-compliance in some patients who do not follow the treatment properly and by the development of resistance to antibiotics used (10). Therefore, there is a growing need to search new therapeutic agents that can hopefully eradicate this significant human pathogen and medicinal plants are a useful source of novel drugs. Several natural products have demonstrated antibacterial activity against $H$. pylori (18) and for centuries a wide variety of plants and substances derived from plants have been used to treat gastrointestinal disorders (2).

Many plants used in Brazil to treat these infections do not

*Corresponding Author. Mailing address: Setor de Bacteriologia do Hospital de Clínicas, UFPR - Rua Padre Camargo, 280. CEP 80.060-240 - Curitiba - PR Brasil.; Tel.: +55 4133607975 Fax: + 55413360 1811.; E-mail: lauracogo@ ufpr.br 
present any scientific evidence of efficacy. It is interesting to determine whether their traditional uses are supported by pharmacological effects or merely based on folklore. Within this context, extracts obtained from Bixa orellana L. (annatto), Chamomilla recutita L. (chamomile), Ilex paraguariensis A. St.-Hil.(roasted and green yerba maté), Malva sylvestris L. (mallow), Plantago major L. (plantain) and Rheum rhaponticum L. (rhubarb) - all of which are used in popular Brazilian cuisine and folk medicine in the treatment of gastrointestinal disorders - were investigated for their anti- $H$. pylori activity.

\section{MATERIALS AND METHODS}

\section{General}

Roots, rhizomes or aerial parts (leaves, stems, seeds, inflorescence) of the plants Bixa orellana L., Chamomila recutita L., Ilex paraguariensis A. St.-Hil., and Plantago major L. were collected in Paraná state, Southern region of Brazil (cities of Morretes, Lapa, Piraquara, and Curitiba respectively) and identified by Dr. Gerdt Hatschbach from Museu Botânico Municipal da Prefeitura de Curitiba, Paraná (MBM), where the vouchers have been deposited. The plants Malva sylvestris L. and Rheum rhaponticum L. were obtained commercially (Flores \& Ervas, Piracicaba, SP, Brazil); the voucher specimens, including identification and classification of plant materials, had been preserved by the company.

The parts of each plant examined and voucher numbers are shown in Table 1.

\section{Extraction of materials}

A total of $50 \mathrm{~g}$ of each plant species was exhaustively extracted with aqueous $96 \%$ ethanol (v/v) by maceration at room temperature. The extracts were obtained after filtration and concentration of the material under reduced pressure until the final volume of $50 \mathrm{ml}$.

Stock solutions of the extracts were made with sterile distilled water at concentration of $100 \mathrm{mg} / \mathrm{ml}$ which were used in the disk diffusion test. Another was made at the same concentration, now with dimethylsulphoxide (DMSO), to perform the determination of the minimum inhibitory concentration. Final concentration of DMSO in the culture medium did not exceed $1 \%$ (12).

\section{Bacterial strains}

A total of eleven clinical isolates of $H$. pylori obtained from the gastric mucosa of patients submitted to upper endoscopy and subsequently diagnosed with gastritis, peptic ulcer disease or gastric cancer were used in the present study. Clinical isolates were coded with the numbers of access BP-84, BP-667, ВР-660, ВН-27, BР-446, BР-650, BР-118, ВР-713, BP-132, BP-652 and F-39 in order to preserve the identity of the patients from whom they were obtained and were previously approved by the Ethics Committee with the issuing of protocol number 982.021/2005-01.

Reference strains H. pylori 26695 (23) and J99 (1), that had their genomes completely sequenced, were tested as control. All the strains were previously evaluated against clarithromycin, amoxicillin, furazolidone, tetracycline and metronidazole, which are antibiotics commonly used in conventional therapy.

\section{Preparation of bacterial suspensions}

An inoculum of each strain used in susceptibility tests was prepared by transferring fresh colonies of the microrganisms in tubes containing sterile physiological saline solution and adjusting the turbidity to the $2.0 \mathrm{McFarland}$ standard (7). This turbidity produces a suspension that corresponds to approximately $6.0 \times 10^{8} \mathrm{CFU} / \mathrm{mL}$ of $H$. pylori.

\section{Disk diffusion test}

In the initial phase, the disk diffusion test was used as screening to analyze the susceptibility of reference strains $H$. pylori 26695 and J99 against to different plant extracts. The bacterial suspensions were spread-plated onto Columbia Agar plates (Oxoid, Basingstoke, UK) supplemented with $10 \%$ defibrinated sheep blood (Newprov, Curitiba, Brazil). Filter paper disks of $6 \mathrm{~mm}$ diameter impregnated with $5 \mathrm{mg}$ of each 
extract $(50 \mu 1$ of stock solutions) were placed onto the surface of the inoculated agar. The plates were incubated at $37^{\circ} \mathrm{C}$ under microaerophilic conditions and observed after 3 to 5 days. The tests were performed in triplicate and the antimicrobial activity was expressed in terms of the mean diameter of the inhibition zone around the disks impregnated with the plant extracts tested, as presented in Table 1.

\section{Determination of the minimum inhibitory concentration}

All the extracts that had produced an inhibition zone greater than $6 \mathrm{~mm}$ in the disk diffusion test were separated to determinate the MIC by the agar dilution method. In addition to reference strains, 11 clinical $H$. pylori isolates were subjected to this test.

The stock solutions made with DMSO were further serially diluted in distilled sterile water and $1 \mathrm{~mL}$ of each dilution was incorporated into $19 \mathrm{~mL}$ of molten Columbia agar (Oxoid, Basingstoke, UK) containing 10\% defibrinated sheep blood (Newprov, Curitiba, Brazil) to be then transferred separately into Petri dishes. The final concentrations of the extracts in the culture medium ranged from 5.0 to 0.625 $\mathrm{mg} / \mathrm{mL}$.

Bacterial suspensions were prepared as described above, and $1 \mu \mathrm{L}$ of each suspension was spotted with a multipoint inoculator onto the surface of the agar plates containing consecutive dilutions of plant extracts. After that, plates were incubated at $37^{\circ} \mathrm{C}$ in a microaerophilic atmosphere for 72 hours and MIC, which is defined as the lowest concentration of an extract that inhibits the visible growth of a microrganism, was determined. For clinical isolates, $\mathrm{MIC}_{50}$ and $\mathrm{MIC}_{90}$ were determined and defined as the concentrations that inhibited, respectively, 50 and $90 \%$ of the strains evaluated. All tests were conducted in triplicate, in addition to growth controls with and without DMSO.

\section{RESULTS AND DISCUSSION}

According to the data reported in Table 1, of all the plant extracts submitted to the screening test, B. orellana L., $C$. recutita L., I. paraguariensis A. St.-Hil. (green and roasted Yerba Maté varieties) and M. sylvestris L. produced inhibition zone diameters by the disk diffusion test. However, there is a disadvantage to this method in that it yields only qualitative results. The absence of objective quantification inherent in the method makes it impossible to compare the degree of antimicrobial activity of the extracts against the $H$. pylori strains investigated (3). For that reason, in the next stage of the study, MIC values were determined by the agar dilution method. The results obtained are shown in Table 2 .

The agar dilution test confirmed an anti-H. pylori activity of all the plant extracts evaluated, with $C$. recutita L. and $I$. paraguariensis A. St.-Hil. (green Yerba Maté variety) showing to be more potent $\left(\mathrm{MIC}_{50}:<0.625 \mathrm{mg} / \mathrm{ml}\right)$ than B. orellana $\mathrm{L}$. $\left(\mathrm{MIC}_{50}: 1.25 \mathrm{mg} / \mathrm{ml}\right)$, I. paraguariensis A. St.-Hil. (roasted Yerba Maté variety) $\left(\mathrm{MIC}_{50}: 1.25 \mathrm{mg} / \mathrm{ml}\right)$ and $M$. sylvestris $\mathrm{L}$ $\left(\mathrm{MIC}_{50}:>5.0 \mathrm{mg} / \mathrm{ml}\right)$. The $\mathrm{MIC}_{90}$ values demonstrated that $I$. paraguariensis A. St.-Hil. was able to inhibit a higher number of clinical isolates when compared with other extracts, although the green Yerba Maté variety $\left(\mathrm{MIC}_{90}: 5.0 \mathrm{mg} / \mathrm{ml}\right)$ was slightly less active than the roasted variety $\left(\mathrm{MIC}_{90}: 2.5 \mathrm{mg} / \mathrm{ml}\right)$.

Previous investigations have demonstrated that $I$. paraguariensis A. St.-Hil., widely consumed as part of the usual diet in Brazil in the form of tea (roasted yerba maté) and chimarrão (green yerba maté), presents several secondary metabolic products that have antimicrobial activity, including phenolic compounds, triterpenes and flavonoids (21). As for $C$. recutita L., this plant has anti-inflammatory and calming properties and is also used to treat gastric colic, and several forms of gastritis, stomatitis, laryngitis and pharyngitis (17). Flavonoids - particularly apeginine - and essential oils are among the main constituents of the plant extract (13).

Research conducted by Stamatis et al. (22) confirmed the anti-H. pylori activity of $C$. recutita L. extract. Although, the plant part used to produce the extract in their work was not specified, which may directly influence the development of results (5).

B. orellana L. and M. sylvestris L. were other plant extracts evaluated by the agar dilution method. The first plant - 
Table 1. Analysis of anti-Helicobacter pylori activity of plant extracts by disk diffusion test.

\begin{tabular}{|c|c|c|c|c|}
\hline \multirow[b]{2}{*}{ Species (voucher numbers) } & \multirow[b]{2}{*}{ Family } & \multirow[b]{2}{*}{ Plant part used } & \multicolumn{2}{|c|}{$\begin{array}{c}\text { Mean of inhibition zone } \\
{ }^{*}(\mathrm{~mm})\end{array}$} \\
\hline & & & $\begin{array}{c}\text { H. pylori } \\
\text { J99 } \\
\end{array}$ & $\begin{array}{c}\text { H. pylori } \\
26695\end{array}$ \\
\hline $\begin{array}{l}\text { Bixa orellana } \mathrm{L} . \\
(\mathrm{MBM} 212752)\end{array}$ & Bixaceae & Seed & 7 & 10 \\
\hline $\begin{array}{l}\text { Chamomilla recutita } \mathrm{L} . \\
(\mathrm{MBM} 189637)\end{array}$ & Asteraceae & Inflorescence & 10 & 11 \\
\hline $\begin{array}{l}\text { Ilex paraguariensis A. St.-Hil. } \\
(\mathrm{MBM} 113738)\end{array}$ & Aquifoliaceae & green leaves & 9 & 10 \\
\hline $\begin{array}{l}\text { Ilex paraguariensis A. St.-Hil. } \\
(\mathrm{MBM} 113738)\end{array}$ & Aquifoliaceae & roasted leaves & 9 & 9 \\
\hline $\begin{array}{l}\text { Malva sylvestris L. } \\
\text { (Flores \& Ervas) }\end{array}$ & Malvaceae & inflorescence and leaves & 10 & 8 \\
\hline $\begin{array}{l}\text { Plantago major L. } \\
(\mathrm{MBM} 243458)\end{array}$ & Plantaginaceae & above-ground parts & $<6$ & $<6$ \\
\hline $\begin{array}{l}\text { Rheum rhaponticum L. } \\
\text { (Flores \& Ervas) }\end{array}$ & Polygonaceae & Root & $<6$ & $<6$ \\
\hline
\end{tabular}

Table 2. MIC (mg/mL) values of plant extracts against clinical isolates and reference strains of Helicobacter pylori.

\section{Plant extracts}

$\begin{array}{llll} & & & \\ & & & \end{array}$


widely used in Brazilian home cooking - is known to contain an essential oil rich in all-E-geranylgeraniol, oxygenated monoterpenes and sesquiterpenes (8). The second one is composed of mucilage, tannins, essential oils and flavonoids (4) reasons why it is used as anti-inflammatory and support in the treatment of different types of infections (14).

Moreover, it is important to note that the most active substances found in the plants screened in these experiments have recognized properties in gastrointestinal digestive diseases and presented stable activity at acid $\mathrm{pH}(9)$.

Increasing antimicrobial resistance is a serious global problem that is present in this important human pathogen (6). Mendonça et al. reported the susceptibility profile involving Brazilian $H$. pylori strains. Resistance rates were observed as to metronidazole, amoxicillin and clarithromycin of 42\%, $29 \%$ and $7 \%$ respectively; values of furazolidone (4\%) and tetracycline (7\%) were also presented (16).

In this study, for each $H$. pylori strain evaluated for the antimicrobial activity of plant extracts, susceptibility to antibiotics used in conventional therapy, was also characterized as shown in Table 3. These strains presented different susceptibility profiles and, in some cases, resistance to one or more antibiotics. Interestingly, the resistant strains evaluated against the different extracts, demonstrated a similar profile when compared to sensitive ones (Table 2).

Table 3. Susceptibility test of Helicobacter pylori reference strains and clinical isolates.

\begin{tabular}{lccccc}
\hline & & & Antibiotics & & \\
\cline { 2 - 6 } Strains & Cla & Am & Fu & Tet & Met \\
\hline 26695* & $\mathrm{S}^{* *}$ & $\mathrm{~S}$ & $\mathrm{~S}$ & $\mathrm{~S}$ & $\mathrm{~S}$ \\
J99* & $\mathrm{S}$ & $\mathrm{S}$ & $\mathrm{S}$ & $\mathrm{S}$ & $\mathrm{S}$ \\
BP-84 & $\mathrm{S}$ & $\mathrm{R}^{* * *}$ & $\mathrm{~S}$ & $\mathrm{~S}$ & $\mathrm{~S}$ \\
BP-667 & $\mathrm{S}$ & $\mathrm{S}$ & $\mathrm{R}$ & $\mathrm{S}$ & $\mathrm{S}$ \\
BP-660 & $\mathrm{S}$ & $\mathrm{S}$ & $\mathrm{S}$ & $\mathrm{S}$ & $\mathrm{S}$ \\
BH-27 & $\mathrm{S}$ & $\mathrm{S}$ & $\mathrm{S}$ & $\mathrm{S}$ \\
BP-446 & $\mathrm{R}$ & $\mathrm{S}$ & $\mathrm{S}$ & $\mathrm{S}$ & $\mathrm{R}$ \\
BP-650 & $\mathrm{S}$ & $\mathrm{S}$ & $\mathrm{S}$ & $\mathrm{S}$ & $\mathrm{S}$ \\
BP-118 & $\mathrm{S}$ & $\mathrm{R}$ & $\mathrm{S}$ & $\mathrm{R}$ & $\mathrm{S}$ \\
BP-713 & $\mathrm{S}$ & $\mathrm{S}$ & $\mathrm{S}$ & $\mathrm{S}$ & $\mathrm{S}$ \\
BP-132 & $\mathrm{S}$ & $\mathrm{S}$ & $\mathrm{S}$ & $\mathrm{S}$ & $\mathrm{S}$ \\
BP-652 & $\mathrm{S}$ & $\mathrm{S}$ & $\mathrm{S}$ & $\mathrm{S}$ & $\mathrm{S}$ \\
F-39 & $\mathrm{S}$ & $\mathrm{S}$ & $\mathrm{S}$ & $\mathrm{S}$ \\
\hline
\end{tabular}

Cla - Clarithromycin, Am - Amoxicillin, Fu - Furazolidone, Tet - Tetracycline, Met - Metronidazole

${ }^{*}$ Reference strains, ${ }^{* *}$ Susceptibility, ${ }^{* * *}$ Resistance.

In summary, a variety of plant species is capable of synthesizing many substances which show antibacterial activity. These properties have been described to extracts of many plants found in Brazilian flora $(19,20)$. However, as regards the plant extracts included in this work, there are no previous studies that evaluate the proposed feature, except for
$C$. recutita L. (22). Results demonstrate that the extracts obtained from plants $B$. orellana L., $C$. recutita L., I. paraguariensis A. St.-Hil. and M. sylvestris L. were capable of inhibiting the in vitro growth of $H$. pylori and could form a promising basis for further investigation in the discovery of new natural anti-H. pylori compounds. 


\section{ACKNOWLEDGEMENTS}

The authors would like to thank Dr. Gerdt Guenther Hatschbach from Museu Botânico Municipal da Prefeitura de Curitiba, for the botanical identification and NEBaC (Núcleo de Estudos em Bacteriologia Clínica de Curitiba), for the financial support.

\section{REFERENCES}

1. Alm, R.A.; Ling, L.S.; Moir, D.T.; King, B.L.; Brown, E.D.; Doig, P.C.; Smith, D.R.; Noonan, B.; Guild, B.C.; deJonge, B.L.; Carmel, G.; Tummino, P.J.; Caruso, A.; Uria-Nickelsen, M.; Mills, D.M.; Ives, C.; Gibson, R.; Merberg, D.; Mills, S.D.; Jiang, Q.; Taylor, D.E.; Vovis, G.F.; Trust, T.J. (1999). Genomic-sequence comparison of two unrelated isolates of the human gastric pathogen Helicobacter pylori. Nature, 397(6715):176-80

2. Borrelli, F.; Izzo, A.A. (2000). The plant kingdom as a source of antiulcer remedies. Phytother. Res., 14, 581-591.

3. Bresolin, T.M.B.; Cechinel Filho, V. (2003). Ciências Farmacêuticas Contribuição ao Desenvolvimento de Novos Fármacos e Medicamentos. Editora Univali, Itajaí, Santa Catarina, Brasil.

4. Buffon, M.C.M.; Lima, M.L.C.; Galarda, I.; Cogo, L. (2001). Avaliação da eficácia dos extratos de Malva sylvestris, Calêndula officinalis, Plantago major e Curcuma zedoarea no controle do crescimento das bactérias da placa dentária. Estudo "in vitro". Visão Acadêmica, 2 (1), 31-38.

5. Cechinel Filho, V.; Yunes, R.A. (1998). Estratégias para a obtenção de compostos farmacologicamente ativos a partir de plantas medicinais. Conceitos sobre modificação estrutural para otimização da atividade. Quím. Nova, 21 (1), 99-105.

6. Chatterjee, A.; Yasmin, T.; Bagchi, D.; Stohs, S. (2004). Inhibition of Helicobacter pylori in vitro by various berry extracts, with enhanced susceptibility to clarithromycin. Mol. Cell. Biochem, 265, 19-26.

7. Clinical and Laboratory Standards Institute (2006). Performance standards for antimicrobial susceptibility testing. Sixteenth informational supplement M100-S16. Clinical and Laboratory Standards Institute, Wayne, PA.

8. Coelho, A.M.S.P.; Silva, G.A.; Vieira, O.M.C.; Chavasco, J.K. (2003). Atividade antimicrobiana de Bixa orellana L. (Urucum). Revista Lecta, $21(1 / 2), 47-54$.

9. Friedman, M.; Jürgens, H.S. (2000). Effect of $\mathrm{pH}$ on the stability of plant phenolic compounds. J. Agr. Food Chem., 48 (6): 2101-2110.

10. Gadhi, C.A.; Benharref, A.; Jana, M.; Lozniewski, A. (2001). AntiHelicobacter pylori activity of Aristolochia paucinervis Pomel extracts. J. Ethnopharmacol., 75 (2-3), 203-205.

11. Kusters, J.G.; Van Vliet, A.H.; Kuipers, E.J. (2006). Pathogenesis of Helicobacter pylori infection. Clin. Microbiol., Rev.19 (3), 449-490.
12. Li, Y.; Xu, C.; Zhang, Q.; Liu, J.Y.; Tan, R.X. (2005). In vitro antiHelicobacter pylori action of 30 Chinese herbal medicines used to treat ulcer diseases. J. Ethnopharmacol., 98 (3), 329-33.

13. Mapeli, N.C.; Viera, M.C.; Heredia, Z.N.A.; Siqueira, J.M. (2005). Produção de biomassa e de óleo essencial dos capítulos florais da camomila em função de nitrogênio e fósforo. Hortic. Bras., 23 (1), 32-37.

14. Martinazzo, A.P.; Martins, T. (2004). Plantas medicinais utilizadas pela população de Cascavel/PR. Arq. Ciênc. Saúde Unipar, 8 (1), 3-6.

15. Megraud, F.; Lehours, P. (2007). Helicobacter pylori detection and antimicrobial susceptibility testing. Clin. Microbiol. Rev., 20 (2), 280322 .

16. Mendonça, S.; Ecclissato, C.; Sartori, M.S.; Godoy, A.P.; Guerzoni, R.A.; Degger, M.; Pedrazzoli Jr, J. (2000). Prevalence of Helicobacter pylori resistance to metronidazole, clarithromycin, amoxicillin, tetracycline, and furazolidone in Brazil. Helicobacter, 5(2):79-83

17. Morais, T.C.; Vieira, M.C.; Heredia, Z.N.A.; Teixeira, I.R.; Ramos, M.B.M. (2006). Produção de biomassa e teor de óleos essenciais da camomila (Chamomilla recutita (L.) Rauschert) em função das adubações com fósforo e nitrogênio. Rev. Bras. Pl. Med., 8 (4), 120-125.

18. Nostro, A.; Cellini, L.; Di Bartolomeo, S.; Di Campli, E.; Grande, R.; Cannatelli, M.A.; Marzio, L.; Alonzo, V. (2005). Antibacterial effect of plant extracts against Helicobacter pylori. Phytother. Res., 19 (3), 198202.

19. Oliveira, D.F.; Pereira, A.C.; Figueiredo, H.C.P; Carvalho, D.A.; Silva, G.; Nunes, A.S.; Alves, D.S.; Carvalho, H.W.P. (2007). Antibacterial activity of plant extracts from Brazilian southeast region. Fitoterapia, 78, 142-145.

20. Sartoratto, A.; Machado, A.L.M.; Delarmelina, C.; Figueira, G.M.; Duarte, M.C.; Rehder, V.L.G. (2004). Composition and antimicrobial activity of essential oils from aromatic plants used in Brazil. Braz. J.Microbiol., 31, 247-256.

21. Schubert, A.; Zanin, F.F.; Pereira, D.F.; Athayde, M.L. (2006). Variação anual de metilxantinas totais em amostras de Ilex paraguariensis A. St. Hil. (erva-mate) em Ijui e Santa Maria, Estado do Rio Grande do Sul. Quím. Nova, 29 (6), 1233-1236.

22. Stamatis, G.; Kyriazopoulos, P.; Golegou, S.; Basayiannis, A.; Skaltsas, S.; Skaltsa, H. (2003). In vitro anti-Helicobacter pylori activity of Greek herbal medicines. J. Ethnopharmacol., 88, 175-179.

23. Tomb, J.F.; White, O.; Kerlavage, A.R.; Clayton, R.A.; Sutton, G.G; Fleischmann, R.D.; Ketchum, K.A; Klenk, H.P.; Gill, S.; Dougherty, B.A.; Nelson, K.; Quackenbush, J.; Zhou, L.; Kirkness, E.F.; Peterson, S.; Loftus, B.; Richardson, D.; Dodson, R.; Khalak, H.G.; Glodek, A.; McKenney, K.; Fitzegerald, L.M.; Lee, N.; Adams, M.D.; Hickey, E.K.; Berg, D.E.; Gocayne, J.D.; Utterback, T.R.; Peterson, J.D.; Kelley, J.M.; Cotton, M.D.; Weidman, J.M.; Fujii, C.; Bowman, C.; Watthey, L.; Wallin, E.; Hayes, W.S.; Borodovsky, M.; Karp, P.D.; Smith, H.O.; Fraser, C.M.; Venter, J.C. (1997). The complete genome sequence of the gastric pathogen Helicobacter pylori. Nature, 388(6642):539-47. 